Article

\title{
The Kalderash Gypsies of Russia in Industrial Cooperation of the 1920s-1930s
}

\author{
Aleksandr V. Chernykh \\ Perm Federal Research Center, Department of History, Archaeology and Ethnography, Russian Academy of Sciences, \\ 614990 Perm, Russia; E-Mail: atschernych@yandex.ru
}

Submitted: 8 January 2020 | Accepted: 11 March 2020 | Published: 4 June 2020

\begin{abstract}
At the end of the 1920s and the beginning of the 1930s, in line with the state economic policy of the time, which was aimed at industrialisation and cooperativisation, and also as part of the implementation of measures to promote a settled way of life for nomadic Gypsies, the Kalderash Gypsies became actively involved within cooperatives and started establishing artels (Gypsy production cooperatives). This article analyses the issue of Gypsy artels, their manufacturing activities, the reasons why they flourished, their decline and their subsequent repression. The study is based on documents from the central and regional archives of the Russian Federation. The historical experience of that period was especially important for the Kalderash community-the establishing of artels helped them to adapt to the emerging economic reality of Soviet society. Indeed, during the following decades artel cooperative associations remained the main form of production and economic interaction with enterprises and organisations. As such, artels existed until the 1980s and then continued to exist within the new economic conditions of the post-Soviet period. Later on, the state never provided special support towards the creation of the Gypsy production associations and took more severe measures to implement its policy. The experience of these cooperatives has also remained a vibrant part of historic tales and been firmly instilled in family oral histories. The historical experience of that period is therefore important for understanding and building a modern policy towards the Gypsy population and solving their social and economic issues.
\end{abstract}

\section{Keywords}

artels; cooperation; economy; Gypsies; industrialisation; Kalderash Gypsies; Roma; Russia; Soviet Union

\section{Issue}

This article is part of the issue "Gypsy Policy and Roma Activism: From the Interwar Period to Current Policies and Challenges" edited by Elena Marushiakova (University of St Andrews, UK) and Vesselin Popov (University of St Andrews, UK).

(C) 2020 by the author; licensee Cogitatio (Lisbon, Portugal). This article is licensed under a Creative Commons Attribution 4.0 International License (CC BY).

\section{Introduction}

The period of the 1920s-1930s in the history of the Soviet state was marked by social and economic changes connected with the industrialisation, cooperation and collectivisation of agriculture. Social and economic changes took place against the backdrop of the new ideologies and the implementation of the Soviet approach regarding the Gypsies across the national policies of that period. The basic concept in terms of national minorities was their integration into the socialist economy and the new Soviet culture. The mechanism of this integration, that was also fully applied to the Gypsies at the time, consisted in the policy defined by 'affirmative ac- tion' and in giving Gypsies certain preferences, including economic ones (Martin, 2001).

In accordance with state economic policy aimed at industrialisation and cooperation, and also as part of the implementation of measures conducive to the sedentary way of life of nomadic Gypsies, certain shifts occurred within conventional Gypsy occupational structures and activities. Along with different ethnic groups they became involved in the economic activities of the Soviet government and joined cooperative movements in villages. Gypsy agricultural collective farms (kolkhoz) were established and the Gypsies participating in industrial production were involved in industrial artels (Gypsy production cooperatives). 
A particular Gypsy group-the Kalderash Gypsiesis one of numerous Gypsy ethnic groups found within Russia and across the rest of the world (Demeter, Bessonov, \& Kutenkov, 2000, pp. 95-96). Their formation as a specific ethnographic group happened in southeast Europe (Romania, Serbia and Greece), and their main occupations were tinning, production and repair of cauldrons and metalwork. The migration of the Kalderash Gypsies from the territory of southeast Europe to Russia occurred between the end of the 19th and the first 30 years of the 20th century.

Once they had settled, it was not long before the Kalderash Gypsies - at that time a fairly numerous group in Russia-became actively involved in the cooperative movement. The specificity of their traditional occupations (tinning and cauldron-making) as well as their town settlement defined their participation in the policy aimed at creation of industrial artels. The objective of this study is to show how the Kalderash Gypsies participated in the economic transformations and economic life of the country in the 1920s-1930s and were involved in the process of industrial cooperation.

\section{Source Database and Historiography}

Despite widespread opinion that events of the Gypsy history are poorly documented, it is worth noting that there is a whole body of source materials that reveal the processes of the Kalderash Gypsies' participation in the cooperative movement of the 1920s-1930s in the Soviet state. Among the sources that enable historical studies to be carried and reveal the details of cooperation processes among the Kalderash Gypsies, are those which were discovered and analysed from the state archive of the Russian Federation, and that represent the main database source. There are official documents and data from public authorities and organisations responsible for such matters (for example, the cottage industry sector of the Moscow Regional Council of Industrial Cooperation, as well as the Moscow Regional Executive Committee). A separate group of sources comprises personnel files of repressed Kalderash Gypsies, including the heads of Gypsy artels, along with various data on the foundation and activities of Gypsy cooperative organisations.

In our research, we analyzed a number of published sources referring to the period of active development and cooperative activity among the Gypsies in the 1920s-1930s. Among them we should mention the articles in the journals Revolutsia i natsional'nosti (The Revolution and Nationalities) and Sovetskoe stroitel'stvo (Soviet State-Building; Bril, 1932, pp. 60-67; Popova \& Bril, 1932, pp. 126-138; "Soveschanie po trudoustroistvu," 1936, pp. 61-72) that feature articles on matters such as the Gypsies' employment and the work of Gypsy industrial cooperatives, as well as analytical and editorial articles on the results of the state policy. Among the sources we should also mention materials taken from Gypsy journals Romani Zoria (Gypsy Dawn) and
Nevo Drom (New Road), which publish separate notes on events in Gypsy life and cooperative artels (Pope, 1932, p. 12; "Romane arteli," 1930). A range of editions also contain some information on the activities of Gypsy cooperatives and may be used as a source for the study. The first of these is the book Tsygany $v$ promkooperatsii (Gypsies in industrial cooperation) by Rogi (1934), which discusses Gypsy cooperation in the artels of the Soviet Union. Despite the fact that the book has an evident ideological context idealising the state policy and its results, the facts that it is based on retain their value.

The available documents demonstrate the official attitude towards the policy and describe a complex of events performed for its implementation, and the problems and reasons that made the Gypsy cooperation more difficult. For the purpose of this study, it is important to take into account statistical data on the number of industrial artels, their financing, staff and the amount of goods produced by cooperatives.

The vision of the Kalderash Gypsies, their attitude towards cooperation, their evaluation of the state events and of personal and group strategies are specified in other documents, such as Gypsy memoirs. These documents also provide information on the period of the 1920s-1930s and the Gypsies' participation in industrial cooperation. For example, from the books by DemeterCharskaya Amaro trayo ande Russiya (Our Life in Russia, 1998) and A Gypsy Girl's Destiny (2003), we learn the story of a Gypsy family and their participation in cooperativisation and the creation of industrial artels in Kharkov and Leningrad in different periods, the motives of the artels' foundation, the range of goods, and other sides of 'cooperative life' in a Gypsy camp. The book by Petrovich The Gypsy Tribe of Saporroni (2007) is less relevant for the subject, conveying only fragmented information on the period researched and the Gypsies' participation in industrial cooperation.

A separate group of sources consists of interviews that were recorded during field studies in the Kalderash Gypsy camps. Unfortunately, the field studies of the 2000 s could not include any record from the generation that took part in the events, so stories about the 1930s and Kalderash participation in cooperative movements were reproduced based on accounts given by the elder generation. They are very fragmented and cover only the main thread of the events; as such, their value lies in the general overview they provide of the period and the events, as well as certain details.

Thus, documentation for this study includes documents and texts that are divergent both in their content and origin, and reflect both the official position of the authorities and the views of the Gypsy community on the process of cooperation. In sum, the sources collated and analysed allow us to trace the peculiarities of the Gypsy artel development and operation from the end of the 1920s through the beginning of the 1930s in the Soviet Union.

The period of Gypsy history in the Soviet Union from the Great Russian Revolution of 1917 up until (and in- 
cluding) the beginning of the so-called Great Patriotic War, which started after Nazi Germany invaded the Soviet Union in 1941, has still not been fully explored. The full range of sources pertaining to this era have not been collated or analysed, and many aspects and matters of Gypsy life during the first decades of the Soviet government are not yet examined (see the historiography of studies on Gypsies in Demeter et al., 2018). Subject matters dealing with the economic changes of the interwar period relating to the Gypsies were reflected only in Russian historical studies, amongst which are the work of Bugay (2012) and Demeter et al. (2000), discussing general matters relating to the changes of that period. The major part of studies touching upon economic policy and the policy of Gypsies settling in the Soviet Union is devoted to their participation in collective farm building (Bugay, 2015; Ivaschenko, 2011; Kamenskikh, 2017; Kilin, 2002), and the policy of Gypsies turning to a sedentary way of life and their participation in the resettlement movement (Kilin, 2005; Kiseleva, 1952; Platunov, 1976). Similarly, their participation in cooperation is fragmentarily discussed only in regard to certain more general issues (Bugay, 2012; Demeter et al., 2000) none of which refer specifically to the Kalderash ethnic group.

International historiography is also represented by a few works discussing the problems of changes during the period through the prism of the Soviet ideology and national policy, the construction of identity and an attempt to involve ethnic minorities including Gypsies into the system of the 'Soviet socialist state-building' (Lemon, 1991, 2000, 2002; Marushiakova \& Popov, 2016; O' Keefe, 2013).

Thus, the historiography of the period reflects important directions of policy regarding Gypsies and certain implementation activities. Until now the problems of its implementation in certain ethnic groups of Gypsies including the Kalderash remain unstudied, and the observations of economic policy in cooperation and the work of industrial artels are limited to general questions. The vast array of source material coupled with the significant gaps present in historiography make this study all the more relevant and allow us to carry out a thorough investigation into the subject.

\section{Legislative Basis of Gypsy Cooperation}

Gypsy participation in cooperativisation was one of the main initiatives of state economic policy and was developing in various forms in the Soviet Union up until the end of the 1930s. Cooperation in agriculture and some fields of industry was declared to be a prior form of agricultural organisation. At the state level, the cooperative movement was regulated by a number of legislative acts of the Soviet state. These were the decrees On Consumer Cooperative Organisations (10th April 1918), On Consumer Cooperation (7th April 1921), On Means of Cooperation (26th July 1921), On Consumer
Cooperation (20th May 1924), amongst others (Vakhitov, 2010, pp. 180-181).

The cooperation movement as a form of organisation was also referenced in documents relating specifically to the Gypsy population, in particular in the Decision of the Presidium of the Central Executive Committee and the Council of People's Commissars of the Soviet Union on assistance to those Gypsies wishing to transit to a sedentary way of life (1st October 1926; Bril, 1932, p. 61), the Decision of the Presidium Central Executive Committee and the Council of People's Commissars of the Russian Soviet Federative Socialist Republic On Granting Land to Those Gypsies Who Transit to a Sedentary Working Way of Life (20th February 1928; Bril, 1932, p. 61). Traditionally, these documents are regarded in the context of events concerning the settling of Russia's Gypsy population and the organisation of Gypsy collective farms, though they played their role in documenting the Gypsies' participation in industry and industrial cooperation as well. The peculiarities of the decisions that were taken at the time and the need for active work in this direction are evidenced in the materials from the Decision of the Presidium of the Central Executive Committee On the Provision of Services to the Working Gypsies (1st April 1932) and the discussion of 'Gypsy matters':

A sedentary way of life, however, does not solve all the issues connected with work among Gypsies because there are some of them who are quite skilled at certain crafts (tinsmiths or coppersmiths) and who want to join industrial artels or join factories. That is why special attention must be paid to matters relating to the Gypsies' involvement in industry and industrial cooperation. (Bril, 1932, p. 66)

The revitalization of work on Gypsy cooperation at the end of the 1920s up until the beginning of the 1930s was also connected with the general direction of the economic policy of the Soviet Union. During the period of the second five-year plan aimed at developing the national economy of the Soviet Union (1933-1937):

Trade cooperation was aimed at...uniting all the artisans and craftsmen and to carry out a lot of work on overcoming the remnants of capitalism in the minds of artel members, turning them into active and conscious builders of socialism. This work demands special attention and energy in the artels with a predominance of members from national minorities, especially Gypsies. (Rogi, 1934, p. 26)

\section{The Creation and Members of Gypsy Artels}

The term 'artel' or 'industrial artel' was widely used both in official documents and colloquially referring to industrial cooperatives. The word 'artel' referred to people's voluntary grouping together for common work. The artisans' shift from individual to collective production 
was defined by the terms 'cooperation,' 'trade cooperation' or 'industrial cooperation.' Artel represented an organized group of people, usually not a numerous one, united for some common production activities. It was based on the principles of self-governance and had an elected leader (a chairman). It had to have a charter-a document that regulated its operation-and an accountant. In the economic conditions of the Soviet system this form of organization of production ensured the interaction with superior executive authorities and helped with the distribution of goods and purchasing of the necessary raw materials.

Information on the first Gypsy artels refers to 1925 (Rogi, 1934, p. 17) while the period in which Gypsy industrial artels flourished occurs in 1928-1933. Official documents give different information on numbers and the placement of Gypsy artels, noting their growth until 1931. The most complete data is available on Moscow, allowing us to trace the dynamics of the Gypsy cooperative movement's development during that period. According to the report of 1934 in Moscow in that time period there were "177 families with a total of 925 Gypsy tinsmiths" ("The all-Russian Central," p. 264). All in all, at that time in Moscow there were about 20 ancestral groups of Kalderash Gypsies. In 1930-1931, Moscow Gypsies were actively involved in industrial cooperation or, as the sources note, "where already in 1930-1931 industrial cooperation started to unite Gypsies" ("The all-Russian Central," p. 264). One of the reasons for this emerged during several meetings of the All-Russian Union of Industrial Cooperation, where it was noted that the National Bureau tasked with carrying out certain activities among national minorities including the Gypsies did not have a provision to speak of for the Gypsies, hence why the work in this direction was initiated (Popova \& Bril, 1932, pp. 133-134). Bril's publication notes that "in 1930 in Moscow there were four artels, in 1931-28 including 1,351 Gypsies or 3,755 people including members of their families" (Bril, 1932, p. 64). Other sources mention there being only 21 artels and that 18 of them consisted of Gypsy tinsmiths ("The allRussian Central," pp. 205, 262). In fact, each Gypsy camp organized its own artel and got the opportunity to buy raw materials and organise the sale of products.

The official list of artels registered in Moscow with their addresses published in A Kolkhoznik's Compilation included 13 artels: Romanian Foreigner, The First SerboRomanian, Krasniy Zabaikalshchik, Greco-Romanian, Serbo-Romanian named after Stalin, Romanian New Way of Life, The Black Sea Emigrant, Red October, The International, Wasteland, The Second Serbo-Romanian, Tiflis Tinsmith, and Ukrainian Tinsmith (Bezludsko \& Germano, 1933, pp. 205-206). Other sources also name artels Yugoslavia, The Red Banner, Athens, Serbia and Romania, Caucasus, Jupiter, The Red Star, Yugoslav, Bakhchysarai, A Southeastern Artel, Red Northerner, etc. ("The all-Russian Central," fol 29). The names of Gypsy artels are not coincidental, but in fact based on three princi- ples. The first group features Soviet and ideologically motivated names which were typical and widespread in that period, such as The Red Banner, Red October, The New Way of Life, etc. The second group consists of names that already include reference to a geographical term from the native region of a certain Gypsy camp that came to Moscow, such as Krasniy Zabaikalets from Siberia, Bakhchysarai from the Crimea and Ukrainian Tinsmith from Ukraine. The third group is related to identification of the Kalderash Gypsies' citizenship, such as Yugoslavia, Athens, Yugoslav, and A Serbo-Romanian Artel. In that period, the majority of the Kalderash Gypsies were the citizens of Romania, Greece and other countries and that fact was also reflected in the naming of the artels.

There is only fragmented information on other regions examining the activities of Gypsy artels. Besides the Moscow region, the cooperative movement involved Gypsies from other territories of the Soviet Union: The Kalderash artels were located in Smolensk, Leningrad, Kharkov, Dnepropetrovsk, Kirov, the Black Sea coastal area, as well as other cities and regions.

The report of 1932 on industrial cooperation among the Gypsy population says that besides Moscow:

In the North Caucasus there are no special Gypsy artels. On January 1, 1933, in combined artels there were 78 Gypsies involved in industrial cooperation efforts. According to the cooperation plan in 1933 a metalworking artel with up to 150 people was to be organized. In the Northern Krai there is one metalworking artel comprising eight people. A workhouse is under construction. In the Central Black Earth Region there are two metalworking artels with totalling 41 cooperative workers. These artels are provided with placement, i.e., lodging and a workhouse. Some Gypsies involved in cooperation could be found in Western Siberia, UkSSR [Ukrainian Soviet Socialist Republic], Eastern Siberia, etc. ("The all-Russian Central," pp. 233-234)

Other sources tell about cooperative artels in Simferopol in Crimea (Barannikov, 1931, p. 84), the Romanian Foreigner artel in Kirov, the New Way artel in the Smolensk region (Bessonov, 2002, p. 5), and the National Metallist artel in Leningrad (Demeter et al., 2018, p. 211). Not always a source gives us precise information on the Kalderash staff of an artel but the majority of metalworking and tinning artels consisted of the Kalderash Gypsies.

Cooperation and the development of industrial artels at the end of the 1920s-1930s involved a lot of the Kalderash Gypsy camps. Such activity was connected with different objectives. This form of industrial organisation coincided with the economic and ideological policy of the Soviet government and was in line with decisionmaking that ensured institutional and economic support from the authorities. Gypsies' interest in creating artels was also connected with the need for an institutional form of interacting with the economic system and power. 
The artel as a construct allowed raw material for production to be obtained and ensured goods could be marketed. The work and conditions of artels is characterized in one of the existing documents:

Despite having an official chairman, charter, stamp, etc., all the Gypsy artels in Moscow are in fact entirely mythical constructs. Inside an artel, all members work on an individual basis. Each Gypsy buys goods on his own, makes products out of them and sells them on behalf of the artel. Such fictitious artels can be found in each tribe and are led by the cleverest man of the tribe. He is also the head or the chief of the tribe. Such fictitious artels led by the chiefs of tribes help families of arrested and convicted Gypsies. They can be found in the tribes of Dukoni, Poroni, Domoni, Chukuroni and Dobrodaya. In all these tribes the families of convicted Gypsies are living well. ("The Agency of the Committee," p. 39)

Due to certain reasons, the Kalderash Gypsies became active participants of the industrial cooperation process during this period. Firstly, the nature of their traditional activities-tinning and metals crafts, while other Gypsy groups focused on trade, blacksmithing and delivery of other services to the rural population. Secondly, the nature of the group settlement-at that time, as well as later, the Kalderash Gypsies aimed at cities and their suburbs. At the same time, the composition of artels corresponded to that of the traditional organisation of the Gypsy community. Since each tribal group or community organised its own artel, it allowed it to preserve traditional forms of leadership and collective decisionmaking, while the industrial organisation corresponded to traditional industrial group 'vortechia' (Demeter et al., 2018 , p. 323). The leadership of the Kalderash Gypsies in cooperation is proved by the following numbers. Out of the 21 Moscow artels only two large production associations (Tsygpishcheprom and Tsygkhimprom) included the representatives of other Gypsy groups ("The all-Russian Central," pp. 262, 205). Other Gypsy groups had a different experience of social and economic activities at that time and it was not connected with industrial production. They took part in the organization of collective farms in rural regions, in trade, and provided services (organized transport artels and creative teams). The closest to the Kalderash Gypsies group of 'Lovari' was trading products and consumer goods (Demeter et al., 2018, p. 98).

An undeniable role in the organisation and popularity of artels at that period was owed to consumer demand and the economic need to provide people with necessary goods that are proved by the documents:

Due to the growth of the network of canteens to cater to the masses, the demand for pots and their repairing is especially high, not only in Moscow but in remote provinces as well. That is why these artels should be afforded due attention, not only from a po- litical but an economic point of view. ("The all-Russian union," p. 5)

Thus, artels as an alternative form of industrial cooperation were profitable and benefited both sides' interests.

\section{The Road to a Sedentary Way of Life: Building Lodgings for Artel Members}

The implementation of state policy on Gypsies in that period was solving two objectives. First, to involve them in the 'socialist system of production' via cooperation, and second, to create industrial artels, thereby providing a solution for them to transition to a sedentary way of life. Due to this reason, documents on the activities of Gypsy artels also discuss matters of granting land and building residential and industrial premises.

The Congress of the Moscow Regional Executive Committee of Workers, Peasants and Red Army Deputies' Soviets on the 15th July 1931 on Gypsy-related matters decided "to help working Gypsies pass from a nomadic to a sedentary way of life and to involve them in industry" ("The all-Russian union," p. 16). Among concrete measures, it ordered the Moscow City Executive Committee to grant land for building shacks to Gypsies working in industries and artels who did not have permanent lodgings in Moscow over five days. In particular, there was a discussion on the possibility of granting land in the Sokolnichesky region, on the 6th versta (mile) of the Yaroslavskaya railway, where the Gypsies had previously settled:

Considering that most Gypsies live in tents which must be changed in winter into heated shacks, the Committee is ordered to get started on this and draw up the plan of works. (“The all-Russian union," p. 16)

To solve the matter of building residential and industrial premises:

By Decree of the Congress of the Moscow Industrial Union (1931), in addition to a number of objectives outlined by the Moscow Chemical Industrial Union, the Moscow Food Union and Metkopromsoyuz [Union of cooperative artels of the Metalworking industry], 120,000 rubles were assigned for enlargement of workshops and 155,000 rubles-for providing all Gypsies with lodgings. ("The all-Russian union," p. 19)

The overall picture of the housing stock construction for Moscow Gypsies, including the Kalderash Gypsies trade artels, is reflected in the work of Bril:

The budget was spent on constructing 35 shacks with 104 rooms in August-October, 1931, while 15 shacks with 20 rooms were repaired and 23 non-residential shacks were equipped for living. Four shacks re- 
mained unfinished. The construction was carried out slowly. There was a lack of construction materials. (Bril, 1932, p. 64)

Indeed, it was not possible to quickly solve the matter of lodging construction and the support of Gypsy families. Finally, it was noted that "only $70 \%$ of them were given residential shacks" ("The all-Russian union," p. 254). The problem of housing in such cases was often solved by Gypsy communities in a traditional way: In the summer, tents were set up, and in winter, the families lived in the shacks or built huts or temporary wooden lodgings.

One of the large-scale projects of the period was the organisation of a Gypsy trade town in the village of Krupino in the Pavlovo-Posadsky District in Moscow region. On the 17th October 1934, the Moscow Regional Council of Trade Cooperation decided to build a trade town that would provide the Gypsy tinsmiths with lodgings, a school and a club. The construction was financed and had to be finished by the 1st September 1935. One hundred families of the Gypsy tinsmiths from the Moscow Gypsy artels The Star, Jupiter, Caucasus, and Yugoslavia had to be relocated there. The project was carried out slowly and was not completed ("The all-Russian Central," pp. 260-261).

Despite the attempts to solve the matter of production basis, Moscow artels were also doing their work in an old way in the streets near the tents. Out of 20 investigated Gypsy artels in Moscow (which included 797 members in October 1931), only two of themRomanian Foreigner and Athens-had their own workshops, the other were working in the open space or in tents. Although officially named 'workshops,' those of the Romanian Foreigner artel represented "barns with leaking roof where the tinning of cauldrons was partially done" ("The all-Russian Central," p. 228).

\section{The End of the Period of Gypsy Artels}

The system of Gypsy artels in which each of them represented a separate community or a camp was quite mobile. This high mobility often led to the fact that a camp, and consequently an artel, was disbanded because of its decision to change lodging. For example, the Athens artel from Moscow was closed because its members moved to the Crimea. The Red Banner artel was dissolved because its members returned to a nomadic way of life. The Bakhchysarai artel "moved away from Moscow" in 1933 ("The all-Russian Central," pp. 201-221).

The period between 1929-1931 witnessed the greatest number of Gypsy artels in existence in Moscow, but from 1932 onwards, the movement towards the liquidation of Gypsy cooperatives began, for which there were several reasons. First of all, we should note the ideological reasons that have been repeatedly cited in different sources. Difficulties in artel organisation and their successful functioning were attributed to the counterrevolutionary activity of the heads of artels-tribal leaders-as well as to the fact that artels were led by bourgeois elements, kulaks, all of which was compounded by the absence of a socialistic system of production. The second reason consisted in organisational difficulties in building an artel's management system encountered by superior organisations, as well as difficulties in the provision of artels with raw material and in managing the system of goods marketing. The third group of reasons may be defined as industrial: The artels had no production basis, tradesmen were forced to work in the streets and in yards without any workshops and equipment. Their work had a seasonal character and in winter all their activities stopped.

No doubt that at first, beginning in 1932, there were several attempts to increase both the productive efficiency of the artels and strengthening them from an ideological standpoint, in order to be better aligned with the Soviet ideologies of the period. Describing organisational measures of 1933, we should mention the fact that Moscow artels were transferred from the administration of the Moscow Trade Union to the system of Metizsoyuz (Union of Metal Products) and Metremsoyuz (Union of Metal Repair) in order to make the management of Gypsy artels more successful.

Organisational and ideological problems were partially solved by the change in management of certain artels and the appointment of new leaders that were not Gypsy. Thus, after the examination of Gypsy artels in the autumn of 1931 among the necessary measures, it was prescribed that those responsible:

Remove the chairmen of the Serbo-Romanian and the Krasniy Zabaikalschik artels, and replace them with people who can guarantee the artels working rights. ("The all-Russian union," p. 5)

It is clear from the reports that "experienced workers of other nationalities were repeatedly sent to help the artels as chairmen, accountants and book-keepers". This did not bring desirable results either because Gypsy communities and artels were preserving their traditional organisation and social institutions and "did not accept" the specialists appointed by superior authorities ("The all-Russian Central," p. 262).

Another method of improving the activities and the situation in artels was either to merge them or to incorporate Gypsy artels into non-Gypsy ones, which had been practised since 1934 . However, for the same previously mentioned reasons, such practice was not supported by Gypsies and resulted in resistance.

From 1932 onwards, in order to "improve the atmosphere in the artels," repressive measures were taken. In the spring and autumn of 1932, several members of the Gypsy artels were arrested:

We had to resort to serious measures and call to account a group of Gypsies that were disrupting and derailing the normal functioning of artels. In March 1932, 
18 people were arrested, 12 of them were chairmen. In September, 80 people were arrested, and are still being held. Some of them also were chairmen. ("The all-Russian Central," p. 159)

In April 1934, the organisational meeting with the Nationality Department of The All-Russian Central Executive Committee (concerning the Gypsy involvement in cooperation in Moscow), ordered the InterMinisterial Commission of the Moscow State Council, together with the Moscow Regional Council of Trade Cooperation and the Metizsoyuz, to work out the issue on the transition to other types of production within five months, as well as to find and equip a common workhouse for the remaining three artels that are to be united into one artel under the Metizsoyuz system ("The all-Russian Central," p. 244).

The final decision on the removal of the Gypsy artels from the Metizsoyuz system in Moscow was issued in 1935, according to the meeting of the Congress' record on the 17th January 1935 ("The all-Russian Central," p. 232). Finally, it was noted that "the attempt by Moscow metal unions to bring about work reorganisation among Gypsies was not a success" ("The all-Russian Central," p. 232).

After the removal of the artels from the Metizsoyuz system, some of them were placed under other cooperative organisations in Moscow: Stamp, Tank, XX Century Autostamp, Exhibitor, etc. Eventually, however, the disbandment of artels put an end to the period of Gypsy cooperation in Moscow, although by that time some Gypsy camps still remained in Moscow. In the KrasnoPresnensky, Dzerzhinsky, Oktyabrsky and Sokolnichesky regions, former members of the artels Jupiter, SerboRomania and Caucasus continued to exist, while not belonging to any industrial or cooperative organisations ("The all-Russian Central," p. 261). Some Moscow Gypsies were moved from their former artels to a newly founded industrial town in the village of Krupino, in the Pavlovo-Posadsky District of Moscow Oblast ("Soveschanie po trudoustroistvu," 1936, p. 69). A new influx of the Gypsy population to Moscow during that period was also limited by the beginning of certification and the complexities associated with obtaining legal residential status in the city. Also, the objective to "rid Moscow of the Gypsies" was put forward ("The all-Russian Central," p. 142). Since 1933, within the framework of the operation to "rid" Moscow of "undesirable elements," several hundreds of Gypsies were sent to Siberia, including a large group of the Kalderash (Bessonov, 2005, pp. 631-640). As a result, the majority of the Gypsy camps left Moscow.

However, in other cities, Gypsy artels continued to exist for some time. Until the end of the 1930s, there were artels in the Moscow Oblast, in particular in the Pavlovo-Posadsky District and in the Smolensk Oblast (Bessonov, 2002).

\section{Results}

The participation of Gypsies in industrial cooperation was part of the state economic and ideological policy of that period, as well as part of a series of measures related to the Gypsy population and its involvement in industrial activities and the settlement of nomadic camps. The policy on Gypsies during that period was part of two directions (economic and national) of domestic policy.

The building of a 'new socialist society' that became one of the most large-scale experiments of the 20th century defined the declaration of new ideas-a shift towards new forms of labour as well as labour and national relations. But the realization of this motto turned out to encounter certain difficulties and contradictions. The experience of the period was unique-in Russian history, there were no other large-scale state measures aimed at the support and development of Gypsy society-from creating the norms of literary language and book publishing to Gypsy collective farms and cooperative artels. There were no other state measures aimed at establishing Gypsy-only production associations with sufficient state support as it was at the turn of the 1920s-1930s, and as was the case in the Gypsy artels.

However, in general, this experience should be considered unfortunate: it had no significant results and no perspectives. Industrial cooperation for the Gypsy community was just a 'historical event' during a short period at the end of the 1920s to the beginning of the 1930s.

At the same time, the participation in cooperation and the concentration of most artels in Moscow and other big cities was the reason for more significant repressive measures of the 1930s related to the Kalderash Gypsies. The failure of the cooperative movement was one of the reasons arrests and convictions happened. In Moscow and Saint Petersburg, where most of the Kalderash Gypsy camps were concentrated, such repressions were most far-reaching. There were many reasons for the repressive policies aimed at the Kalderash Gypsies but the failures of the cooperative movement and the wave of abuse in artels, as along with the upholding of community orders in artels, were the main ones (Bessonov, 2002).

\section{Historical Experience and Modern Times}

Similarly, the historical experience of that period was important for the Kalderash community-the stage of artels helped them to adapt to the emerging economic reality of Soviet society.

With the support of the state authorities, the artels managed to procure the necessary raw materials and market their goods as per the conditions of a planned economy and the absence of market relations. In Soviet times, it was the first mass experience of the Kalderash Gypsies' interaction with the state authorities and the state economic system. Subsequently, this experience allowed for the preservation of traditional areas of 
employment-that of metalworkers, tinsmiths and cauldron makers - throughout the Soviet period up until now. This experience allowed them to adapt to the existing economic relations. It was also essential for adapting traditional institutions and the social structure of the Gypsy community to the existing legal and economic system.

The dissolution of artels and the beginning of mass repression at the end of the 1930 s significantly impacted the resettlement system. The Kalderash Gypsies left Moscow and only some families would later live in the city. If during the period of artels the majority of Gypsy camps were concentrated in Moscow and the Moscow region, later those dispersed and began resettling across different cities and regions of Russia.

After the Great Patriotic War and the stabilization of the country's economic life, artel organisation and the experience of artel industrial workers was needed once again. During the following periods, it remained the main form of production and economic interaction with enterprises and organisations, with Gypsy artisans concluding agreements with collective farms, catering industries and factories and certain types of work. Such a way of working existed until the 1980s. In the conditions of perestroika and the post-Soviet period, it continued under new economic conditions-in certain Russian cities, Gypsy artisans once again became active participants of relevant, legal cooperative movements.

The failure of Gypsy production associations in the 1920s-1930s had a bearing on the approach of state policy. Later, the state never created Gypsy-only production associations. The following policy on Gypsies was based on their involvement in existing production associations and factories. In comparison with the 1920s-1930s, when cooperation was declared and when there was the support from the state institutions, more severe measures geared towards implementing the policy were taken during the post-war period, including administrative punishment and criminal penalties.

The historical experience of the 1920s-1930s has not been properly evaluated until now. Furthermore, its role in shaping a modern policy on Gypsies, in order to help overcome their social and economic problems, should not be underestimated.

\section{Conflict of Interests}

The author declares no conflict of interests.

\section{References}

Barannikov A. (1931). Tsygany SSSR: Kratkiy istorikoetnograficheskiy ocherk [The Gypsies of the USSR: A brief historical and ethnographic essay]. Moscow. Centrizdat.

Bessonov, N. (2002). Ubity za trudolubie [Killed for their diligence]. 30 Octiabria, 23, p. 5.

Bessonov, N. (2005). Tsygane v Rossii: prinuditelnoe osedanie [Gypsies in Russia: The forced settling down]. In O. Glezer \& P. Polyan (Eds.), Rossia i ee regiony v XX veke: Territoria, rasselenie, migratsii [Russia and its regions in the XX century: Territory, resettling, migrations] (pp. 631-640). Moscow: Gumanit.

Bezludsko, M., \& Germano, A. (1933). Romanae organizatsii [Gypsy organizations and trade]. In Angil ke buty. [So trabi te dgenes romaska vgei dro kolkhozo [A Kolkhoznik's Collection] (pp. 205-206). Moscow.

Bril, M. (1932). Trudyaschiesya tsygane $v$ riady stroitelei sotsialisma [Working Gypsies among the builders of Socialism]. Revolutsia i Natsionalnosti, 7, pp. 60-66.

Bugay, N. (2012). Tsygane Rossii: Obschestvo, adaptatsia, consensus (1900-2010) [The Gypsies of Russia: Society, adaptation, consensus (1900-2010)]. Moscow: Kuchkovo pole.

Bugay, N. (2015). Zabytye stranitsy zhizni obschestva tsygan v Soyuze SSR 1930-1960 [Forgotten pages of the Gypsy community's life in the USSR in the 1930-1960]. Privolzhsky naychnyi vestnik, 7(47), pp. 46-65.

Demeter, N., Chernykh, A., Abramenko, O., Belugina, N., Bugay, N., Vayman, D., . . . Shapoval, V. (2018). The Gypsies. Moscow. Nauka.

Demeter, N., Bessonov, N., \& Kutenkov, V. (2000). Istoria tsygan: Novy vzglyad [The history of Gypsies: The new vision]. Voronezh: IPF Voronezh.

Demeter-Charskaya, O. (1998). Amaro trayo ande Russiya [Our life in Russia]. Moscow.

Demeter-Charskaya, O. (2003). Sud'ba tsyganki [A Gypsy girl's destiny]. Moscow: Publisher Mozhaev A. A.

Ivaschenko, V. (2011). Tsyganskie sudbi: Istoria, trud, etnografia [The Gypsies' lives: History, labour, ethnography]. Rostov-na-Donu: Donizdat.

Kamenskikh, M. (2017). Vovlechenie tsyganskogo naselenia $v$ kolkhoznoe stroitelstvo na Urale $v$ kontse 1920-1930 gody [The involvement of the Gypsy population into kolkhoz organization in the Urals in the late 1920s-1930s]. The Bulletin of Perm Scientific Centre UB RAS, 4, pp. 10-17.

Kilin, A. (2002). Sozdanie tsyganskikh kolkhozov na Urale: Interesy storon [The creation of Gypsy kolkhozes in the Urals: Interests of the participating parties]. In Materialy konferentsii Chetvertye Tatischevskie chtenia: Priroda, byt i kultura Urala [Materials of the Conference: The Forth Tatischev's Readings. Nature, everyday life and culture in the Urals] (pp. 261-264). Yekaterinburg.

Kilin, A. (2005). Politika perevoda tsygan na osedlyi obraz zhizni: Problemy realizatsii (1926-1937) [The shift in the policy regarding Gypsies towards a sedentary way of life: The problems of implementation (1926-1937)]. Document, archive, istoria, sovremennost, 5, pp. 187-226.

Kiseleva, T. (1952). Tsygany evropeiskoi chasti Soyuza SSR i ikh perehod ot kochevania k osedlisti [The Gypsies of the European part of the USSR and the shift from nomadic to a sedentary way of life]. Moscow.

Lemon, A. (1991). Roma (Gypsies) in the Soviet Union 
and the Moscow Teatr 'Romen.' Nationalities Papers, 19(3), 359-372.

Lemon, A. (2000). Between two fires: Gypsy performance and Romani memory from Pushkin to postsocialism. Durham, NC, and London: Duke University Press.

Lemon, A. (2002). "Form" and "function" in Soviet Stage Romani: Modeling metapragmatics through performance institutions. Language in Society, 31(1), 29-64.

Martin, T. (2001). The affirmative action empire: Nations and nationalisms in the Soviet Union, 1923-1939. Ithaca, NY: Cornell University Press.

Marushiakova, E., \& Popov, V. (2016). Gypsies in central Asia and the Caucasus. London: Palgrave Macmillan.

O' Keefe, B. (2013). New Soviet Gypsies: Nationality, performance, and selfhood in the early Soviet Union. Toronto: University of Toronto Press.

Petrovich, M. (2007). Tsyganskoe plemya sapporoni [Gypsy tribe of sapporoni]. Saint-Petersburg: Anima.

Platunov, N. (1976). Pereselencheskaya politika sovetskogo gosudarstva l ee osuschestvlenie v SSSR (1917-iun'1941) [The resettlement policy of the Soviet state and its implementation in the USSR (1917-June 1941)]. Tomsk: University of Tomsk Press.

Pope, R. (1932). Bolshoe delo: Tainyi sud Mihaya [A big affair: Mikhai's secret court]. Nevo Drom, 5, p. 12.
Popova, E., \& Bril, M. (1932). Tsygane v Soyuze SSR [Gypsies in the USSR]. Sovetskoe stroitel'stvo, 2, pp. $126-138$.

Rogi, M. (1934). Tsygane v promkooperatsii [Gypsies in trade cooperation]. Moscow and Leningrad: Koiz.

Romane arteli. (1930). Nevo Drom, 1, p. 15.

Soveschanie po trudoustroistvu i kulturno-bytovomy obsluzhivaniu tsygan [The meeting on Gypsies employment, welfare and recreation]. (1936). Revolutsia $i$ natsional'nosti, 2, pp. 61-72.

The Agency of the Committee of State Safety of the USSR, Moscow and Moscow Oblast. Fund 10035. List 1. Fol. 74091. Alimov Andrey Ivanovich (Kulai Le Parasco). GARF-The State Archive of the Russian Federation.

The all-Russian Central Executive Committee. Fund R1235. List. 123. Fol. 29. Case on the state of work on the involvement of Gypsy workers in cooperation. GARF-The State Archive of the Russian Federation.

The all-Russian union of industrial cooperation. Fund A5449. List 1. Fol. 1412. Protocol of the meeting of the handicraft industry sector of the Supreme Board of the National Economy of the RSFSR on October 22, 1931. GARF-The State Archive of the Russian Federation.

Vakhitov K. (2010). Istoria promyslovoi kooperatsii v Rossii [History of consumer cooperation in Russia]. Moscow: ITK "Dashkov and K".

\section{About the Author}

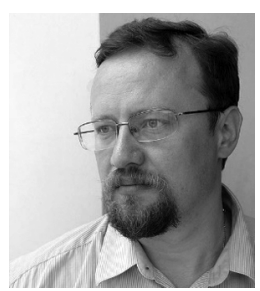

Aleksandr V. Chernykh has a DrSC in History and is a Corresponding Member of the Russian Academy of Sciences. He is also a Professor and the Head of the Sector of Ethnological Research. His research interests are ethnology, social anthropology, and traditional culture of ethnic minorities of the Russia. He has than 30 scientific works devoted to Gypsies. 